\title{
Novel approach to evaluate the dynamic variation of wind drift and evaporation losses under moving irrigation systems
}

S-H. Sadeghi ${ }^{\mathrm{a},}$, T. Peters ${ }^{\mathrm{a}}$, M.Z. Amini ${ }^{\mathrm{a}}$, S. L. Malone ${ }^{\mathrm{b}}$ and H.W. Loescher ${ }^{\mathrm{c}}$,

${ }^{a}$ Dept. of Biological Systems Engineering, Washington State University, Prosser, WA

${ }^{\mathrm{b}}$ US Forest Service, Rocky Mountain Research Station, Fort Collins, CO

${ }^{c}$ The National Ecological Observatory Network (NEON), Boulder, CO, and the Institute of

Alpine and Arctic Research (INSTAAR), University of Colorado, Boulder, CO

${ }^{*}$ Corresponding author.a

E-mail address: s.hossein.sadeghi@wsu.edu 
The increased need for water and food security requires the development of new approaches to save water through irrigation management strategies, particularly for center pivot irrigation. To do so entails monitoring of the dynamic variation in wind drift and evaporation losses (WDELs) of irrigation systems under different weather conditions and for relatively long time periods. The historical catch can method has limited our ability to address this goal. Here, a new and easy-to implement methodology, called the strip test, was developed and validated against the catch can technique. Our results showed strong agreement between the catch can method and the strip test for determining the average water application efficiency (WAE $\approx 1$-WDEL). Because the strip test method was measured for shorter intervals compared to the catch can method, the variables influencing WAE were able to be compared during each test. WAE had a large variance over time, which was controlled, in part, by wind speed $\left(>4 \mathrm{~m} \mathrm{~s}^{-1}\right)$. Site-specific characterisation of WDEL is needed to apply this technique. Once applied, it can provide a better understanding of WAE behaviour over the time, and enhance the capability of predicting results for the optimising water use in sprinkler irrigation.

Keywords: wind drift; evaporation loss; center pivot; catch can test; water application efficiency; weather condition; strip test

\begin{tabular}{|c|c|c|c|}
\hline \multicolumn{2}{|c|}{ Nomenclature } & $\mathrm{T}$ & Temperature $\left({ }^{\circ} \mathrm{C}\right)$ \\
\hline J & $\begin{array}{l}\text { an index representing the tip number } \\
\text { within each 5-min interval }\end{array}$ & WAE & water application efficiency \\
\hline $\mathrm{L}$ & $\begin{array}{l}\text { total distance between the first and the } \\
\text { last row of cans }(\mathrm{m})\end{array}$ & WDEL & $\begin{array}{l}\text { wind drift and evaporation } \\
\text { loss }\end{array}$ \\
\hline $\mathrm{m}$ & $\begin{array}{l}\text { the total number of tips over 5-min for } \\
\text { strips B }\end{array}$ & $\mathrm{WAE}_{\mathrm{can}}$ & $\begin{array}{l}\text { WAE from the catch can } \\
\text { method }\end{array}$ \\
\hline $\mathrm{n}$ & $\begin{array}{l}\text { the total number of tips over 5-min for } \\
\text { strips A }\end{array}$ & $\mathrm{WAE}_{\text {Strip }}$ & WAE from the strip method \\
\hline $\mathrm{p}$ & $\begin{array}{l}\text { the total number of tips over 5-min for } \\
\text { strips C }\end{array}$ & $z_{i}$ & $\begin{array}{l}\text { the catch can irrigation } \\
\text { depth after taking } \\
\text { evaporation into account } \\
\text { (m) }\end{array}$ \\
\hline
\end{tabular}




\begin{tabular}{|c|c|c|c|}
\hline $\mathrm{q}_{\mathrm{av}}$ & average sprinkler discharge $\left(\mathrm{m}^{3} \min ^{-1}\right)$ & $\alpha$ & $\begin{array}{l}\text { Tipping bucket calibration } \\
\text { coefficient }\end{array}$ \\
\hline $\mathrm{q}_{\mathrm{A}, \mathrm{j}}$ & $\begin{array}{l}\text { the flow rate for strips A after the } j \text { th tip } \\
\left(\mathrm{m}^{3} \min ^{-1}\right)\end{array}$ & $\beta$ & strip width (m) \\
\hline $\mathrm{q}_{\mathrm{B}, \mathrm{j}}$ & $\begin{array}{l}\text { the flow rate for strips B after the } j \text { th tip } \\
\left(\mathrm{m}^{3} \min ^{-1}\right)\end{array}$ & $\Delta t$ & $\begin{array}{l}\text { time difference between two } \\
\text { consecutive tips }\end{array}$ \\
\hline $\mathrm{q}_{\mathrm{C}, \mathrm{j}}$ & $\begin{array}{l}\text { the flow rate for strips } C \text { after the } j \text { th tip } \\
\left(\mathrm{m}^{3} \min ^{-1}\right)\end{array}$ & $\lambda$ & sprinkler head spacing $(\mathrm{m})$ \\
\hline RH & relative humidity & & \\
\hline
\end{tabular}

\subsection{Introduction}

In many areas of the world, 70 to $80 \%$ of available fresh water is currently used in agriculture (Hoekstra \& Chapagain, 2007). However, it is expected that as population and economy grow, a larger fraction of available water will be required for non-agricultural purposes, e.g., urban and industrial applications (Boserup, 2005). Also, climate change has already limited water resources for many regions of the world (Li et al. 2007; McVicar et al., 2007; Bandyopadhyay et al., 2009), which has a negative feedback to future agricultural sustainability and food security (Rockström et al., 2009; Gheysari et al., 2015). Optimising agronomic water use efficiency through new irrigation management approaches is one way to mitigate this negative feedback, while at the same time, maximizing economic returns (Evans, 2008; Montazar \& Behbahani, 2007; Delirhasannia et al., 2010).

Center pivot irrigation systems currently irrigate more than 12.5 million ha around the globe (Spears, 2003; Sadeghi \& Peters, 2013), and they are steadily replacing traditional flood irrigation and other types of sprinkler irrigation. The key advantage of center pivots is their ability to apply water on a regular and consistent basis (Peters \& Evett, 2007). In addition, pivots can easily irrigate large fields with relatively low labour and energy costs, and they are also adaptable to different and changing management objectives (Keller \& Bliesner, 1990; Kincaid et al., 1996). Despite these advantages, center pivot systems are unable to irrigate the whole circle in a perfectly uniform manner. The 'global' water 
application uniformity is dependent on the water application efficiency (WAE), i.e., the amount of water that reaches the soil surface for storage divided by the amount of water that leaves the sprinkler nozzles for any given area (Harrison, 1993, ANSI 1995). It is generally recognised that typical center pivots will have an average WAE of $80-85 \%$ (Musick et al., 1988; Neibling, 2009). The temporal WAE is, however, not necessarily within this range and mostly depends on wind drift and evaporation losses (WDELs, where WAE $\approx 1$-WDELs), i.e., spray losses (Scheneider, 2000; Ortiz et al., 2009) that occur during the irrigation event. The most rapid center pivots complete a full rotation in $\sim 1 \frac{1 / 2}{2}$ days, but 2-to-4 days per rotation is typical. Over this time period a wide range in weather (synoptic), diurnal, and microclimate conditions occurs. On a large scale, this contributes to poor application uniformity under center pivots, as well as inaccurate estimates of actual water application depths. A grower using an irrigation system with inconsistent uniformity must then apply additional water in order to adequately irrigate the entire field, often applying water when and where it is not needed. Overwatering some areas increases the risk of potential runoff, nutrient leaching and soil loss (Santos et al., 2003; Bauder et al., 2008). Non-uniform watering will also result in non-uniform plant growth reducing overall yield and producing a loss of quality (Ortiz et al., 2010).

Finding practical solutions to reduce the temporal variation in center pivot water application efficiency is clearly needed. Catch-can based studies have been conducted in the past to measure the WAE of pressurised irrigation systems (Christiansen, 1942; Frost \& Schwalen, 1955; George, 1955; Kraus, 1966; Sternburg, 1967; Yazar et al., 1984; Robinson, 1973; Kohl et al., 1987; Musick et al., 1988; Seginer et al., 1991; Abo-Ghobar, 1992; Tarjuelo et al., 1999; McLean et al., 2000; Faci et al., 2001; Ocampo et al., 2003; Playán et al., 2005; Silva, 2006; Bavi et al., 2009; Ortiz et al., 2009; King et al., 2012). The testing usually involved the placement of multiple catch cans in a networked pattern and estimating 
the amount of water being delivered to the cans (assuming spatial independence of the measurements, Loescher et al., 2002). Although the catch-can test is a standardised international test (ISO 11545) that is quick and suitable for discretely evaluating system performance during the growing season, it cannot be used to measure the continuous variation of the WAE due to (i) its lack of spatial representation, i.e., n-size sampling theory (Loescher et al., 2014), (ii) its inability to reflect the dynamic variation of WAE, i.e., more than 30 -min is needed and only a single data point is provided at the end of the experiment, (iii) low catch efficiency occuring under windy conditions (Kohl, 1972; Marek et al., 1985; Livingston et al., 1985; Hindawi et al., 2005) and; (iv) it is a cumbersome and timeconsuming technique (Sadeghi \& Peters, 2012; Uddin et al., 2010). For example, recent catch can based studies carried out by Playán et al. (2005) and Ortiz et al. (2009) used only 52 and 47 irrigation tests to evaluate WDELs under a center pivot irrigation.

Optimising irrigation WAE requires a new approach to advance our understanding of the abiotic controls on the continuous variation of WDELs under different weather conditions. As such, estimates of WAE (and subsequently WDELs) must be determined over both short- and long-sampling periods that span the microclimate (5 to 60-min) diurnal (24h), and synoptic (several days) controls. Using a larger catchment area can also be measured more frequently and be a possible solution to achieve this goal, i.e., collector strips. This method has been previously used to evaluate the uniformity of spray distribution from nozzles in laboratory conditions (rf. Sayinci and Bastaban, 2010) as well as estimating surface runoff and/or sediment on different soil textures (rf. Sharpley, 1995; Ghadiri et al., 2001). However, to date, no effort has been made to use this technique for measuring the WAE under irrigation systems. Here, we propose, develop and validate the strip method as a cost effective technique to monitor WAE under different weather conditions for center pivot and linear move irrigation systems. 


\subsection{Materials and Method}

We used a two-span stationary linear move irrigation system located at the Irrigated Agricultural Research and Extension Center (IAREC), Washington State University, Prosser, WA, USA $\left(46^{\circ} 15^{\prime} 6.40^{\prime \prime} \mathrm{N}, 119^{\circ} 44^{\prime} 21.64^{\prime \prime} \mathrm{W}, 351 \mathrm{~m}\right.$ a.s.l). Each span was $60 \mathrm{~m}$ long and consisted of twenty sprinklers installed at a $3 \mathrm{~m}$ spacing and $1.5 \mathrm{~m}$ a.g.l. Sprinklers were sixgroove spinner yellow plate spray (model S3000, Nelson Irrigation Corp., Walla Walla, WA, USA), and were equipped with $103.42 \mathrm{KPa}$ pressure regulators and $4.37 \mathrm{~mm}$ diameter nozzles (\#22, Nelson Irrigation Corp). The nozzle flow rate was characterised before this study as $131 \mathrm{~min}^{-1}$ from measures of discharged volume and irrigation time.

To capture the amount of water being delivered to the soil surface, three small surface runoff catchments (i.e., referred to as strips, $21 \mathrm{~m} \times 1 \mathrm{~m} \times 0.1 \mathrm{~m}$ ) were made from a wooden berm, impervious tarp on the soil, and a sub-surface mounted tipping bucket rain gauge (TB1L; Hydrological Services Pty Ltd, Australia) (Fig. 1). These strips were placed underneath- and perpendicular- to the lateral movement of the linear irrigation system (see A, $\mathrm{B}$ and $\mathrm{C}$ in Fig. 2). Preliminary characterisation of the sprinklers determined a maximum wetted radius of $10 \mathrm{~m}$ under very windy conditions $\left(\sim 6 \mathrm{~m} \mathrm{~s}^{-1}\right)$. Because the linear system was stationary and positioned at the center of the collection strips, the $21 \mathrm{~m}$ span length was therefore assumed to be a representative area. PVC pipes ( $25 \mathrm{~mm}$ diameter) were attached to the top of each berm so that catchment surface area was well defined (i.e., $21 \mathrm{~m}^{2}$ ). The soil was bare with a slope of $0.1 \%$ (Nakawuka et al. 2014).

Because the prevailing wind direction for the area under study was SW to NE, we positioned the strips to capture the full (not partial) effect of the prevailing winds. Hence, the strips were placed in the middle of the left span and close to the middle tower (Fig. 2), which also minimised the effect of edge sprinklers underestimating WDELs. It should be noted that the 20 sprinklers on the right span were not used during this study to avoid additional runoff 
not contributed by our experimental design. We also objectively chose the placement of the strips to assure spatial representation (i.e., effect of the catchment location) of the WDELs in relation to the distance from the sprinklers, i.e., the right berm of strip $\mathrm{C}$ was located exactly beneath the 6 th sprinkler whereas those of strips $B$, and A were $1 \mathrm{~m}$ and $2 \mathrm{~m}$ away from the 7th, and the 8th sprinkler, respectively (Fig. 2). The strips were installed by gently levelling the soils to remove any depressions from the surface.

The berms were made of wood and were funnelled downstream such that the runoff was oriented toward the outlet (Fig. 1). Irrigation water was collected within the strip using a large waterproof tarpaulin that was placed over the strips creating impermeable surface to prevent any infiltration during the experiment. The tarpaulin was green in colour to simulate the presence of a very short and uniform plant canopy. Attention was paid not to produce significant wrinkles when installing the tarpaulin. The edges of the tarpaulins at each side of the strips were attached to the ground by being buried in adjacent soil and held down with heavy objects. For additional precaution, 6 rectangular asphalt shingles $(1020 \mathrm{~mm} \times 340 \mathrm{~mm}$ $\times 30 \mathrm{~mm}$ ) were placed inside each strip every $3 \mathrm{~m}$ to fix the inside tarpaulin to the ground and prevent the wind from blowing underneath.

Local meteorology was measured $2 \mathrm{~m}$ upwind of strip B (Fig. 2) in the prevailing wind direction using a cup anemometer (014A-L; Campbell Scientific Inc., Logan, UT, USA), a wind direction sensor (024A-L; Campbell Scientific Inc.) and a temperature-relative humidity probe (T and RH, PC72V; Michell Instruments Ltd., UK), and data were acquired at 1 s execution interval by a datalogger (CR-3000, Campbell Scientific Inc.). All sensors were mounted at $0.75 \mathrm{~m}$ a.g.l. height.

At the outlet of each strip (runoff catchment), a pit was dug $(0.9 \mathrm{~m} \times 0.7 \mathrm{~m} \times 0.4 \mathrm{~m})$ to install the tipping bucket rain gauges below grade. The tipping buckets were covered by triangular shaped wooden shields to prevent bias due to wind, dust, evaporative demand 
and/or falling soil (Fig. 1). Their data were acquired at a $0.01 \mathrm{~s}$ execution interval by the datalogger. A trench was dug to drain the wastewater produced by these tipping buckets.

A total of 8 controlled irrigation tests were carried out in 2014 as part of this study, (Table 1). Among these, 2 tests were made under windy conditions, and the remaining tests were conducted during calmer winds with high (and sometimes extreme) temperatures (Table 1). An instantaneous flow rate $(q)$ for each of the three strips was estimated by:

$q=\frac{0.5 \times \alpha}{\Delta t}$

where 0.5 is the bucket volumetric capacity $(0.51) ; \alpha$ is the calibration coefficient determined for each of the three tipping buckets; and $\Delta t$ is time difference between two consecutive tips (min). 5-min average values of the WAE $\left(W A E_{5 \min }\right)$ were then calculated by dividing the average flow rate from all 3 strips by the average sprinkler nozzle flow rate $\left(q_{a v}=131 \mathrm{~min}^{-1}\right)$, and correcting by the ratio of strip width $(\beta)$ to sprinkler head spacing $(\lambda)$ as follows:

$W A E_{5 \min }=\frac{\left(\sum_{j=2}^{n} q_{A, j}+\sum_{j=2}^{m} q_{B, j}+\sum_{j=2}^{p} q_{C, j}\right) \times \lambda}{q_{a v}(n+m+p-3) \beta}$

where, $n, m$ and $p$ are the total number of tips over 5-min for strips $\mathrm{A}, \mathrm{B}$ and $\mathrm{C}$, respectively; $j$ is an index representing the tip number within each 5-min interval (i.e., $1 \leq j \leq \mathrm{n}$ for strip $\mathrm{A}$, $1 \leq j \leq \mathrm{m}$ for strip $\mathrm{B}$ and $1 \leq j \leq \mathrm{p}$ for strip $\mathrm{C}) ; q_{A, j}, q_{B, j}$ and $q_{C, j}$ are the flow rates for strips $\mathrm{A}, \mathrm{B}$ and $\mathrm{C}$, respectively, after the $j$ th tip, which were evaluated using Eq. 1 . For example, $q_{B, 4}$ refers to the flow rate for strip B after the occurrence of the 4th tip. For each sigma, $j$ starts from 2 since the first flow rate could not be calculated unless the second tip occurred. The value of 3 inserted in the denominator was due to the fact that for each strip and for each timing interval (i.e., 5-min), the total number of calculated flow rates was always equal to the total number of tips for that strip minus 1. 
To validate this study, catch cans were also concurrently installed and collected during these events. For this purpose, 108 plastic commercial cans (110 mm diameter, 130 mm height) were installed inside - and outside strips A and B. The spatial design consisted of 6 rows of 18 catch cans each with $1 \mathrm{~m}$ spacing. Two rows (out of the 6) were placed in the centreline of the strips. The duration of each test was at least 45-min (Table 1). After the sprinklers were shut off, the catch can collection was estimated in $<20$-min. Water depth was calculated by dividing the volume collected by the surface area of the aperture of the empirically, by filling a single can with a known volume of water, placing it outside the influence of the irrigation, and measuring it before and after the test (Playan et al., 2005, Ortiz et al., 2009). To decrease the collector evaporation losses, the cans were pre-wetted before a test.

WAE from the catch can method was estimated by:

$W A E_{c a n}=\frac{\lambda \times 1 \sum_{i=1}^{108} z_{i}}{L q_{a v} t}$

where $\lambda$ is sprinkler head spacing $(3 \mathrm{~m}) ; L$ is total distance between the first and the last row of cans $(6 \mathrm{~m}) ; q_{a v}$ is sprinkler discharge $\left(0.013 \mathrm{~m}^{3} \mathrm{~min}^{-1}\right) ; t$ is irrigation time (min) (Table 1); $1 \mathrm{~m}^{2}$ is the surface area represented by each catch can; $z_{i}$ is the catch can irrigation depth after taking evaporation into account $(\mathrm{m})$ and; $\mathrm{n}$-size $=108$ total number of catch cans, i.e., $\mathrm{i}=$ $1,2, \ldots, 108$.

Estimates of WAE from the strip and catch can methods had different sampling intervals, i.e., 5-min verses the total period of the test, respectively. Because the aim was to validate the strip results against the catch can method, a global WAE was derived (here called $W A E_{\text {Strip }}$ ) for the strip test by inserting $n, m$ and $p$ (for strips A, B and C respectively) in Eq. (2) as the total number of tips for each complete test. 


\subsection{Data Analysis (Statistics)}

Mixed modelling methods with variance-covariance matrices explicitly formulated to appropriately account for the random effects of the experimental design, were used to evaluate drivers of WAE and the differences in $W A E_{\text {Strip }}$ and $W A E_{C a n}$ (catch can method). Variance-covariance parameters were estimated via restricted maximum likelihood using the SAS procedure PROC MIXED (v.9.4, SAS Institute Inc. Cary, NC, USA). The model included fixed effects for the method (catch can and strip), average wind direction $(\theta)$, and average and maximum air temperature $\left({ }^{\circ} \mathrm{C}\right)$, relative humidity, and wind speed $\left(\mathrm{m} \mathrm{s}^{-1}\right)$. Random effects were included for the test number ( 1 to 8 ) and test duration (min).

Mixed modeling methods were used to explore the effects of environmental conditions on the $W A E_{5 \min }$ with fixed (temperature, wind speed and relative humidity) and random effects (test and time). Explanatory variables were explored strategically due to high correlation among parameters (Table 2) to prevent multi-colinearity. Parameter selection was based on the Wald chi-square statistics, and parameters were removed from the model if they were not influential $(P>0.05)$. Goodness-of-fit statistics, Akaike's information criteria (AIC) and Bayesian information criteria (BIC), were used to compare models. AIC and BIC are model selection statistics appropriate for non-nested models, which measure how close fitted values are to true values, with a penalty for the number of parameters in the model (Littell et al., 2006). At each step in model selection, the significance of each model parameter was evaluated to ensure that the final model had the lowest AIC and BIC values. To test for differences among levels of categorical variables, least square means were produced, which are the marginal predicted mean values for the model-dependent variable given all other variables in the model are at their average values. Differences among means were tested with the Tukey-Kramer multiple comparisons test. Assumptions of normality and homoscedasticity were evaluated visually by plotting residuals. 


\subsection{Results and Discussion:}

\subsection{Validation with catch can data}

Good agreement was observed between the catch can $\left(W A E_{C a n}\right)$ and the strip $\left(W A E_{\text {Strip }}\right)$ methods for all tests, with a maximum difference being only $2.3 \%$ (Fig. 3). Tests 1 and 2 showed the largest difference between methods, which occurred under high wind speeds (Figs. 3). The mixed effects model supports these observations showing that there was no significant difference between methods $(p=0.4135)$, and that the $W A E_{\text {Strip }}$ and $W A E_{C a n}$ had both a significant negative relationship with average wind speed $(p=0.0829)$ (Table 3; Fig. 4). The interaction between methods and wind speed, suggests that as wind speeds increased, the $W A E_{C a n}$ was lower than $W A E_{\text {Strip }}(p=0.0587$; Table 3; Figs. 4 and 5c). However, high correlation between explanatory factors (Table 2) restricted the inclusion of more than one explanatory factor in the final mixed effects model.

Wind speed was highly correlated with mean and maximum air temperature $(p<$ 0.001; Table 2). High covariance between wind speed, air temperature, and relative humidity suggests that interacting effects may be important though difficult to quantify due to the sample size, and high spatial and temporal covariance. Linear relationships between the difference between methods, air temperature (Fig. 5a), relative humidity (Fig. 5b), and wind speed (Fig. 5c) were also observed and this suggested that $W A E_{\text {Strip }}$ was enhanced by lower temperatures $\left(<24^{\circ} \mathrm{C}\right)$ and appeared to be less sensitive to higher wind speeds $\left(>1.69 \mathrm{~m} \mathrm{~s}^{-1}\right.$; Fig. 5). The $W A E_{C a n}$ was higher when temperatures were $\sim 24^{\circ} \mathrm{C}$ and at lower wind speeds $\left(<1.69 \mathrm{~m} \mathrm{~s}^{-1}\right.$; Fig. 5).

\subsection{Sources of errors}

It was assumed that random effects were the same for both approaches. It was also assumed that systematic sources were the same for both measurement systems, but the effects of these sources differed. For example, i) collection efficiency: there is a variance in the sprinkler's 
ability to distribute water spatially, which was assumed to be better captured by the larger strips compared to the smaller surface area. Hendawi et al. (2005) reported that catch can collection efficiency is generally reduced under high wind conditions and becomes further reduced when droplet sizes are very small (i.e., $<0.5 \mathrm{~mm}$ ). In our study, however, most of the droplet sizes were between 1 to $2 \mathrm{~mm}$ (King, private communication) thus the catch can efficiency should be $>95 \%$ (Hendawi et al., 2005). Here, the collection efficiency of both systems was assumed to be $100 \%$, because the sources of error differ in part, i.e., water collected by strips is continuous verses discrete collection by the catch cans. However, under high wind conditions, the $W A E_{C a n}$ was lower than $W A E_{\text {Strip }}$ (Figs. 3 and 4). Thus, if the collection efficiency of cans is fully accounted for, our estimate of $2.3 \%$ error reported may be reduced, ii) evaporative losses and surface capacitance: the amount of surface area and surface capacitance differ between the two methods. This exposes the strip method to potentially large evaporative losses. To account for this potential bias, wind speed and temperatures (i.e., water temperature under the irrigation source which is close to the wet bulb temperature Sadeghi et al. (2013), and tarpaulin temperatures that change with incident solar radiation, air and water temperatures) should be measured directly. The WAE results were re-evaluated by neglecting the water evaporation from the cans during the experiments. It was concluded that there was a relative difference of only $0.1 \%$ in the final (total) WAE output by the catch can method. Therefore, this affect was discounted in the interpretation as other researchers have done (e.g. Playan et al., 2005; Ortiz et al., 2009; King et al., 2012). Empirically assessing this source of bias was not within the scope of this study, and it was assumed to be lower in magnitude than the bias due to the (in)ability to assess the changing environmental conditions that control WAE, and i.e., temporal averaging-which is within the scope of this study, and iii) Hysteresis effect: It is acknowledged that evaporative losses change exponentially throughout the day due to changing environmental conditions, e.g., 
increases in air temperature (Campbell and Norman, 1998). Although the strips exposed more surface area than the cans, both were subject to the same diurnal hysteresis in evaporative demand. It can be assumed that the overall evaporative quantities are orders of magnitude smaller than the gross collection amounts that we wish to compare, and to discount this effect. In addition, the water captured water by the strips was in the form of droplets which quickly reached the main stream that was flowing towards the outlet. Therefore, the effect of hysteresis on the measured WAE was likely to be minimal.

\subsection{Comparison with other methods}

As an alternative method for measuring WAE over short timing intervals a network of tipping bucket rain gauges (TBRG) could be used. The TBRG method has several shortcomings, such as; i) the need to have numerous (and costly) collectors with the same collection area as the strip method, and to account for a spatial representative mean and variance (Loescher et al. 2002), ii) higher maintenance efforts/cost, iii) additional source of error in breakthrough volume and over spill in the tipping mechanism (a the common problem of the tipping mechanism is not operating sufficiently rapidly to cope with quantity of water delivered to the collector), and iv) the spatial averages would be compromised if one (or perhaps several) tipping buckets were damaged during the experiment. Interpolation would be a good solution to fill the gap in spatial coverage, but it would also introduce another source of uncertainty. This source of uncertainty would be further compounded if wind speed and direction changed during the test (rf. Dechmi et al., 2003). The strip method on the other hand, does not embody any of these operational shortcomings or uncertainties.

\subsection{Measuring $W A E_{5 \min }$}

$W A E_{5 \min }$ was variable and changed even over a 45-min test (e.g test 6 in Fig. 6). In tests with very high wind speeds, $W A E_{5 \min }$ varied from $80 \%$ to $92 \%$ and from $77 \%$ to $95 \%$ (Fig. 6). 
Variations in $W A E_{5 \min }$ persisted at lower values under low wind conditions (tests 3 to 8 ). This can be attributed to the abrupt changes of wind direction during the experiments, (see Fig. 4). All these observations confirm again that the catch can method failed to capture the dynamic variation of the WAE with time.

\subsection{Drivers of the WAE.}

In a similar manner to the effects of environment on $W A E_{C a n}$ and $W A E_{S t r i p}, W A E_{5 \min }$ decreased with both temperature and wind speed and increased with relative humidity. However, only the correlations with temperature $(p=0.002)$ and wind speed $(\mathrm{p}<0.001)$ were significant, not for relative humidity (Table 4). When considering the $W A E_{\text {Strip }}$ and $W A E_{c a n}$, only wind speed showed a significant relationship (Table 2). This indicates that evaluating the WAE over short time intervals (e.g. 5 min) may be a better way to study its drivers even though the instantaneous effects of the weather variables on $W A E_{5 \min }$ cannot be established due to the inherent time lag in the measurements.

Although the relationship between relative humidity and WAE was not significant, neither for $W A E_{5 \min }$ nor for $W A E_{\text {Strip }}$, it is likely that this parameter is also important driver of WAE, as has been shown for WDELs using center pivots (Harrison 1993; McLean et al., 2000; Playán et al., 2005; Ortiz et al., 2009). This further suggests that all the drivers of evapotranspiration (ET) also control WAE, i.e., Penman Montieth, or Priestly \& Taylor equations (Priestly \& Taylor 1972, Steiner et al. 1983, Penman \& Unsworth, 1990, Keller \& Bliesner, 1990; Allen et al., 1998). The question is, under what conditions do specific parameters exert the most control. For example, Clark and Finley (1975) found winds $>4.5$ $\mathrm{m} \mathrm{s}^{-1}$ controlled evaporative losses (i.e. aerodynamic conductance terms became important, Steiner et al. 1983), and at lower windspeeds, vapour pressure deficit exerted a greater control. A similar conclusion can be drawn from Playán et al. (2005) who found that wind speed best explained WAE when data from both day and night measurements were grouped 
together, but not when night time data was used alone, suggesting that aerodynamic conductance with a lack of (night time) evaporative demand does not control ET. While biophysical models can provide insight on the abiotic drivers of WAE, irrigation is inherently applied to the agronomic system, thus imposing interactive effects of the abiotic drivers and the physical structure of the irrigation system. For example, Playán et al. (2005) suggested that sprinkler height above the surface roughness should be taken into account given the vertical wind profiles, and Steiner et al. (1983) found that orientation of the irrigation system to mean wind direction can also affect WAE. Not only are the designs of sprinklers becoming important, but also how they are situated in the agronomic system, i.e. height within the surface layer distance from roughness elements (Monteith \& Unsworth 1990). Taken in concert, our study also suggests that the integration of biophysical approaches (e.g. Penman-Montieth controls on ET), hydrological approaches to the estimate of WAE, runoff, and capacitance (e.g. a Rutter-type model, Calder et al. 1986, Loescher et al. 2002, 2005) along with design attributes of the irrigation system and where it is located above the plant canopy, will advance our understanding of WAE and help better optimise irrigation efficiencies as a whole.

\subsection{Conclusions}

A strip method of water distribution measurement was proposed for the measurement of wind drift and evaporation losses under linear moving or center pivot sprinkler irrigation systems and this was validated against the standard catch can technique. Compared to the catch can method, this new approach has the advantage of measuring WDELs continuously and provides more information on how changing weather and environmental conditions affect WAE Our results indicated that the instantaneous WAE (here measured every $5 \mathrm{~min}$ ) is dynamic in time and space, and can make site- and system-specific characterisation more pertinent. In general, it was concluded that the difference between the maximum and the 
minimum $W A E_{5 \min }$ is high when wind speeds are high. The strip technique should assist in developing a predictive capacity (for the WAE) and meet the increasing need for enhancing the efficiency of delivering irrigation water. The technique could provide the context for future investigations to more accurately estimate the continuous variation of wind drift and evaporation losses over short time intervals, for long time periods, and when canopy is present or not.

\subsection{Acknowledgements:}

S-HS acknowledges the four societies that have provided support and have bestowed awards as part of this study: American Society of Civil Engineers Freeman Fellowship (2013), Soil Science Society of America graduate student award from the soil and water management and conservation section (2013), the American Society of Agronomy outstanding graduate student award from the environmental quality section (2013), and the American Water Resource Association graduate student award from the - Washington section (2013). HWL acknowledges the National Science Foundation (NSF) for ongoing support. The NEON is a project sponsored by the NSF and managed under cooperative support agreement (1029808) by NEON, Inc. Any opinions, findings, and conclusions or recommendations expressed in this material are those of the authors and do not necessarily reflect the views of our sponsoring agencies. This commentary would not have taken shape if it were not for meaningful engagement with community members.

References:

Abo-Ghobar, H. M. (1992). Losses from low-pressure center-pivot irrigation systems in a 23-32. 
Allen, R. G., Pereira, L. S., Raes, D., \& Smith, M. (1998). FAO Irrigation and drainage paper No. 56. Rome: Food and Agriculture Organization of the United Nations, pp. 300.

ANSI/ASAE Standards S436, 1995. Test procedure for determining the uniformity of water distribution of center-pivot, corner pivot, and moving lateral irrigation machines equipped with spray or sprinkler nozzles. In: ASAE Standards. ASAE, St. Joseph, MI.

Bauder, T. A., Andales, A. A., \& Waskom, R. M. (2008). Nitrogen and Irrigation Management. Colorado State University Extension. pp 2.

Bavi, A., Kashkuli, H. A., Boroomand, S., Naseri, A., \& Albaji, M. (2009). Evaporation losses from sprinkler irrigation systems under various operating conditions. Journal of Applied Science, 9(3), 597-600.

Bandyopadhayay, A., Bhadra, A., Raghuwanshi, N. S., \& Singh, R. (2009). Temporal trends in estimates of reference evapotranspiration over India. Journal of Hydrologic Engineering. 14(5), 508-518.

Boserup, E. (2005). The conditions of agricultural growth: The economics of agrarian change under population pressure. Transaction Publishers. pp 137.

Calder, I.R., Wright, I.R., \& Murdiyaso, D., (1986). A study of evaporation from a tropical rain forest-west Java. Journal of Hydrology, 89, 13-31.

Campbell, G. S., \& Norman, J. M. (1998). An introduction to environmental biophysics. Springer-Verlag New York, 286 pp..

Christiansen, J. E. (1942). Irrigation by sprinkling. University of California, Agricultural Experiment Station B-670, Berkeley, CA. pp.110-116.

Clark, R. N., \& Finley, W. W. (1975). Sprinkler evaporation losses in the Southern Plains.

Dechmi, F., Playán, E., Cavero, J., Faci, J. M., \& Martínez-Cob, A. (2003). Wind effects on solid set sprinkler irrigation depth and yield of maize (Zea mays). Irrigation Science, 22(2), 67-77. 
Dechmi, F., Playán, E., Cavero, J., Martínez-Cob, A., \& Faci, J. M. (2004). Couple crop and solid set sprinkler simulation model. I: model development. Journal of Irrigation and Drainage Engineering, ASCE, 130(6), 499-510.

Delirhasannia, R., Sadraddini, A. A., Nazemi, A. H., Farsadizadeh, D., \& Playán, E. (2010). Dynamic model for water application using center pivot irrigation. Biosystems Engineering, 105(4), 476-485.

Evans, R. G., \& Sadler, E. J. (2008). Methods and technologies to improve efficiency of water use. Water Resources Research, 44(7), doi: 10.1029/2007WR006200

Faci, J.M., Salvador, R., Playán, E., \& Sourell, H. (2001). A comparison of fixed and rotating spray plate sprinklers. Journal of Irrigation and Drainage Engineering, ASCE, 127 (4), 224-233.

Frost, K. R. \& Schwalen, H. C. (1955). Sprinkler evaporation losses. Agricultural Engineering, 36(8), 526-528.

Geary, B., Johnson, D. A., Hamm, P. B., H. C. \& Cummings, T. F. (1999). Fungicide application for late blight management: a boom attached to a center pivot irrigation system. Plant Disease, 83(6), 512-515.

George, T. J. (1955). Evaporation from irrigation sprinkler sprays as determined by an electrical conductivity method. Unpublished M.S. Thesis. University of California, Davis, CA.

Ghadiri, H., Rose, C. W., \& Hogarth, W. L. (2001). The influence of grass and porous barrier strips on runoff hydrology and sediment transport. Transactions of the ASAE, 44(2), 259-268.

Gheysari, M., Loescher, H. W., Sadeghi, S. H., Mirlatifi, S. M., Zareian, M. J., \& Hoogenboom, G. (2015). Water-yield relations and water use Efficiency of maize 
under Nitrogen fertigation for semiarid environments: experiment and synthesis. Advances in Agronomy, 130, 175-229.

424

425

Harrison, K. A. (1993). Water application efficiency measurements for three sprinkler packages in Georgia. San Diego, California, Irrigation Association Technical Conference Proceedings. United States of America. pp. 8.

Hendawi, M., Molle, B., Folton, C., \& Granier, J. (2005). Measurement accuracy analysis of sprinkler irrigation rainfall in relation to collector shape. Journal of irrigation and drainage engineering, 131(5), 477-483.

Hoekstra, A. Y., \& Chapagain, A. K. (2007). Water footprints of nations: water use by people as a function of their consumption pattern. Water Resources Management, 21(1), 3548.

ISO-11545. (1994). Agricultural irrigation equipment. Center pivot and moving lateral irrigation machines with sprayer or sprinkler nozzles. Determination of uniformity of water distribution.

Keller, J., \& Bliesner, R. D. (1990). Sprinkler and trickle irrigation. Van Nostrand Reinhold, New York. pp 652.

Kincaid, D., Salomon, K., \& Oliphant, J. (1996). Drop size distributions for irrigation sprinklers. Transactions of the ASAE, 39(3), 839-845.

King, B. A., Dungan, R. S., \& Bjorneberg, D. L. (2012). Evaluation of center pivot sprinkler wind drift and evaporation measurement technique. In ASABE Annual International Meeting (Vol. 2012 July, pp. 1-11), Dallas TX.

Kohl, R. A. (1972). Sprinkler precipitation gage errors. Transaction of the ASAE, 15(2), 264265.

Kohl, K. D., Kohl, R. A., \& DeBoer, D. W. (1987). Measurement of low pressure sprinkler loss. Transactions of the ASAE, 30(4), 1071-1074. 
447 Kraus, J. H. (1966). Application efficiency of sprinkler irrigation and its effects on microclimate. Transactions of the ASAE, 9(5), 642-645.

449

450

451

452

453

454

455

456

457

458

459

460

461

462

463

464

465

466

467

468

469

Li L. J., Zhang, L., Wang, H., Wang, J., Yang, J. W., Jiang, D. J., Li, J. Y., \& Qin, D. Y. (2007). Assessing the impact of climate variability and human activities on Streamflow from the Wuding River basin in China. Hydrological Processes, 21(5), 3485-3491.

Littell, R. C., Milliken, G. A., Stroup, W. W., Wolfinger, R. D., \& Schabenberger, O., (2006). SAS for mixed models, 2nd Edition. SAS Institute Inc., Cary NC, 813 pp.

Livingston, P., Loftis, J. C., \& Duke, H. R. (1985). A wind tunnel study of sprinkler catchcan performance. Transactions of the ASAE, 28(6), 1961-1965.

Loescher, H. W., Ayres, E., Duffy, P., Luo, H., \& Brunke, M., (2014). Spatial variation in soil properties among North American ecosystems and guidelines for sampling designs. Plos One, 9(1), e83216.

Loescher, H.W., Gholz, H. L., Jacobs, J. M., \& Oberbauer, S. F. (2005). Energy dynamics and modeled evapotranspiration from a wet tropical forest in Costa Rica. Journal of Hydrology, 315, 274-294.

Loescher, H.W., Powers, J. S., \& S.F. Oberbauer, S. F., (2002). Spatial variation of throughfall volume in an old growth tropical rain forest. Journal of Tropical Ecology, $18,397-407$.

Marek, T. H., Schneider, A. D., Baker, S. M., \& Popham, T. W. (1985). Accuracy of three sprinkler collectors. Transactions of the ASAE, 28(4), 1191-1195.

McLean, R. K., Ranjan, S., \& Klassen, G. (2000). Spray evaporation losses from sprinkler irrigation systems. Canadian Agricultural Engineering, 42(1), 1-8. 
McVicar, T. R., Niel, T. G. V., Li, L.T., Hutchinson, M. F., Mu, X. M., \& Liu, Z. H. (2007) Spatially distributing monthly reference evapotranspiration and pan evaporation considering topographic influences. Journal of Hydrology, 338 (3-4), 196-220.

Montazar, A., \& Behbahani, S. M. (2007). Development of an optimized irrigation system selection model using analytical hierarchy process. Biosystems engineering, 98(2), $155-165$.

Monteith, J. L., \& Unsworth, M. H. (1990). Principles of Environmental Physics. Edward Arnold, London. pp. 291.

Musick, J. T., Pringle, F. B., \& Walker, J. D. (1988). Sprinkler and furrow irrigation trendsTexas High Plains. Applied engineering in agriculture, 4(1), 46-52.

Neibling, H., Shewmaker, G. \& Falen, G. (2009). Center Pivot Management for Forage Production. In: Proceedings, 2009 Western Alfalfa and Forage Conference, December 2-4, 2009, Reno, Nevada. UCCE, University of California, Davis 95616.

Nakawuka, P., Okwany, R. O., Peters, T. R., Desta, K., \& Sadeghi, S. H. (2014). Efficacy of boom systems in controlling runoff under center pivots and linear move irrigation systems. Applied Engineering in Agriculture, ASAE, 30(5), 797-801.

Ocampo, L. R., Thomas, D. L., Hook, J.E., \& Harrison, K. A. (2003). Comparative loss study of four different sprinkler packages on center pivot systems under South Georgia conditions. ASBE Paper No. 032013, St. Joseph, MI.

Ortiz, J. N., Tarjuelo, J. M., \& De Juan, J. A. (2009). Characterization of evaporation and drift losses with center pivots. Agricultural Water Management, 96(11), 1541-1546.

Ortiz, J. N., De Juan, J. A., \& Tarjuelo, J. M. (2010). Analysis of water application uniformity from a center pivot irrigator and its effect on sugar beet $(<\mathrm{i}>$ Beta vulgaris </i> L.) yield. Biosystems engineering, 105(3), 367-379. 
Peters, R. T., \& Evett, S. R. (2007). Spatial and temporal analysis of crop conditions using multiple canopy temperature maps created with center-pivot-mounted infrared thermometers. Transactions of the ASAE, 50(3), 919-927.

Playán, E., Salvador, R., Faci, J. M., Zapata, N., Martínez-Cob, A., \& Sánchez, I. (2005). Day and night wind drift and evaporation losses in sprinkler solid-sets and moving laterals. Agricultural Water Management, 76(3), 139-159.

Priestly, C.H.B., \& Taylor, R.J., (1972). On the assessment of the surface heat flux and evaporation using large scale parameters. Monthly Weather Review, 100, 81-92.

Robinson, F. E. (1973). Increase in conductivity of irrigation water during irrigation. Agronomy Journal, 65(1), 130.

Rockström, J., Falkenmark, M., Karlberg, L., Hoff, H., Rost, S., \& Gerten, D. (2009). Future water availability for global food production: the potential of green water for increasing resilience to global change. Water Resources Research, 45(7).

Sadeghi, S. H., \& Peters, T. (2012). Analytical determination of distribution uniformity for microirrigation tapered laterals laid on uphill and horizontal slopes. Journal of Irrigation and Drainage Engineering, ASCE, 139(6), 483-489.

Sadeghi, S. H., \& Peters, T. (2013). Adjusted friction correction factors for center-pivots with an end-gun. Irrigation Science, 31(3), 351-358.

Sadeghi, S. H., Peters, T. R., Cobos, D. R., Loescher, H. W., \& Campbell, C. S. (2013). Direct Calculation of Thermodynamic Wet-Bulb Temperature as a Function of Pressure and Elevation. Journal of Atmospheric and Oceanic Technology, 30(8), $1757-1765$.

Santos, F. L., Reis, J. L., Martins, O. C., Castanheira, N. L., \& Serralheiro, R. P. (2003). Comparative assessment of infiltration, runoff and erosion of sprinkler irrigated soils. Biosystems Engineering, 86(3), 355-364. 
Sayinci, B., \& Bastaban, S. (2011). Spray distribution uniformity of different types of nozzles and its spray deposition in potato plant. African Journal of Agricultural Research, 6(2), 352-362.

Schneider, A. D. (2000). Efficiency and uniformity of the LEPA and spray sprinkler methods: A review. Transactions of the ASAE, 43(4), 937-944.

Seginer, I., Kantz, D., \& Nir, D. (1991). The distortion by wind of the distribution patterns of single sprinklers. Agricultural Water Management, 19(4), 341-359.

Sharpley, A. N. (1995). Dependence of runoff phosphorus on extractable soil phosphorus. Journal of Environmental Quality, 24(5), 920-926.

Silva, L. L. (2006). The effect of spray head sprinklers with different deflector plates on irrigation uniformity, runoff and sediment yield in a Mediterranean soil. Agricultural Water Management 85(3), 243-252.

Spears, T. D. (2003). Irrigating efficiently to feed the world in 2050. In Proceedings of the 2003 irrigation association international exposition and technical conference, The Irrigation Association, Falls Church, VA (pp. 411-422).

Steiner, J. L., Kanemasu, E. T., \& Clark, R. N. (1983). Spray Losses and partitioning of water under a center pivot sprinkler systems. Transactions of the ASAE, 26 (4), 1128-1134.

Sternburg, Y. A. (1967). Analysis of sprinkler irrigation losses. Journal of Irrigation and Drainage Engineering, ASCE, 93(4), 11-124.

Tarjuelo, J. M., Montero, J., Carrion, P. A., Honrubia, F. T., \& Calvo, M. A. (1999). Irrigation uniformity with medium size sprinklers. Part II: Influence of wind and other factors on water distribution. Transactions of the ASAE, 42(3), 677-689.

Uddin, J., Smith, R., Hancock, N., \& Foley, J. P. (2010). Droplet evaporation losses during sprinkler irrigation: an overview. In Australian Irrigation Conference and Exhibition 2010: Proceedings (pp. 1-10). Irrigation Australia Ltd. 
544 Yazar, A. (1984). Evaporation and drift losses from sprinkler irrigation systems under 545 various operating conditions. Agricultural Water Management, 8, 439-449.

546 
547 Figure Captions

548 Fig. 1. Conceptual representation of a strip and its tipping bucket.

549 Fig. 2. Experimental design of the field sampling.

550 Fig. 3. $W A E_{\text {Strip }}, W A E_{C a n}$ and average wind speed.

551 Fig. 4. Linear relationships between wind speed $\left(\mathrm{m} \mathrm{s}^{-1}\right)$ and $W A E_{\text {Strip }}$ and $W A E_{C a n}(\mathrm{P}<0.001)$.

552 Fig. 5. Linear relationship between the residuals from $W A E_{\text {Strip }}-W A E_{C a n}$ and (a) air 553 temperature, (b) relative humidity, and (c) wind speed.

554 Fig. 6. Time series of (a) wind speed, (b) air temperature, (c) relative humidity, and (d) the $555 W A E_{5 \min }$ for each test.

556 
Tables

Table 1. Time, duration of each test, and weather conditions.

\begin{tabular}{ccccccc}
\hline Test & Date & $\begin{array}{c}\text { Test Duration } \\
(\mathrm{min})\end{array}$ & $\begin{array}{c}\text { Average } \\
\text { Temperature }\left({ }^{\circ} \mathrm{C}\right)\end{array}$ & $\begin{array}{c}\text { Average RH } \\
(\%)\end{array}$ & $\begin{array}{c}\text { Average Wind } \\
\text { Speed }(\mathrm{m} / \mathrm{s})\end{array}$ & $\begin{array}{c}\text { Maximum Wind } \\
\text { Speed }(\mathrm{m} / \mathrm{s})\end{array}$ \\
\hline 1 & 8 May & 90 & 15.5 & 71.9 & 3.9 & 5.7 \\
2 & 9 May & 90 & 16.2 & 43.8 & 4.8 & 5.9 \\
3 & 25 Aug. & 60 & 23.8 & 54.8 & 1.1 & 1.7 \\
4 & 25 Aug. & 90 & 27.4 & 42.9 & 0.9 & 1.5 \\
5 & 26 Aug. & 90 & 19.9 & 63.5 & 0.6 & 1.2 \\
6 & 26 Aug. & 45 & 25.6 & 44.7 & 0.9 & 1.2 \\
7 & 26 Aug. & 90 & 32.6 & 24.7 & 0.9 & 1.7 \\
8 & 28 Aug. & 90 & 25.2 & 46.6 & 1.5 & 1.9 \\
\hline
\end{tabular}


Table 2. Pearson's correlation coefficients for explanatory variables and $\mathrm{WAE}_{\text {Strip }}$ and $\mathrm{WAE}_{\mathrm{Can}}$.

\begin{tabular}{|c|c|c|c|c|c|c|c|}
\hline $\begin{array}{c}r \\
p \text {-value }\end{array}$ & $\begin{array}{c}\text { Wind } \\
\text { Direction }\end{array}$ & $\begin{array}{l}\text { Air Temperature } \\
\text { (Average) }\end{array}$ & $\begin{array}{c}\text { Air Temperature } \\
\text { (Max) }\end{array}$ & $\begin{array}{c}\text { Relative Humidity } \\
\text { (Average) }\end{array}$ & $\begin{array}{c}\text { Relative } \\
\text { Humidity (Max) }\end{array}$ & $\begin{array}{l}\text { Wind Speed } \\
\text { (Average) }\end{array}$ & $\begin{array}{l}\text { Wind Speed } \\
\text { (Max) }\end{array}$ \\
\hline Wind Direction & & & & & & & \\
\hline $\begin{array}{l}\text { Air Temperature } \\
\text { (Average) }\end{array}$ & $\begin{array}{r}-0.7178 \\
0.0017\end{array}$ & & & & & & \\
\hline $\begin{array}{l}\text { Air Temperature } \\
\text { (Max) }\end{array}$ & $\begin{array}{r}-0.6945 \\
0.0028\end{array}$ & $\begin{array}{l}0.9936 \\
<.0001\end{array}$ & & & & & \\
\hline $\begin{array}{l}\text { Relative Humidity } \\
\text { (Average) }\end{array}$ & $\begin{array}{l}0.6989 \\
0.0026\end{array}$ & $\begin{array}{r}-0.7797 \\
0.0004\end{array}$ & $\begin{array}{r}-0.7217 \\
<.0001\end{array}$ & & & & \\
\hline $\begin{array}{l}\text { Relative Humidity } \\
\text { (Max) }\end{array}$ & $\begin{array}{l}0.7054 \\
0.0023\end{array}$ & $\begin{array}{r}-0.7996 \\
<.0001\end{array}$ & $\begin{array}{r}-0.7338 \\
<.0001\end{array}$ & $\begin{array}{l}0.9850 \\
<.0001\end{array}$ & & & \\
\hline $\begin{array}{l}\text { Wind Speed } \\
\text { (Average) }\end{array}$ & $\begin{array}{l}0.3611 \\
0.1695\end{array}$ & $\begin{array}{r}-0.7473 \\
0.0009\end{array}$ & $\begin{array}{r}-0.7665 \\
<0001\end{array}$ & $\begin{array}{l}0.2609 \\
03291\end{array}$ & $\begin{array}{l}0.3562 \\
0.1757\end{array}$ & & \\
\hline $\begin{array}{l}\text { Wind Speed } \\
\text { (Max) }\end{array}$ & $\begin{array}{l}0.3500 \\
0.1839\end{array}$ & $\begin{array}{r}-0.7517 \\
<.0001\end{array}$ & $\begin{array}{r}-0.7573 \\
0.0007\end{array}$ & $\begin{array}{l}0.3232 \\
0.2220\end{array}$ & $\begin{array}{l}0.4274 \\
0.0987\end{array}$ & $\begin{array}{l}0.9886 \\
<.0001\end{array}$ & \\
\hline WAE $_{\text {Strip/Can }}$ & $\begin{array}{l}0.1232 \\
0.6494\end{array}$ & $\begin{array}{l}0.3147 \\
0.2352\end{array}$ & $\begin{array}{l}0.3569 \\
0.1748\end{array}$ & $\begin{array}{l}0.2323 \\
0.3865\end{array}$ & $\begin{array}{l}0.1382 \\
0.6098\end{array}$ & $\begin{array}{r}-0.7778 \\
<.0001\end{array}$ & $\begin{array}{r}-0.7680 \\
<.0001\end{array}$ \\
\hline
\end{tabular}


Table 3. Mixed modeling effects for $\mathrm{WAE}_{\text {Strip }}$ and $\mathrm{WAE}_{\mathrm{Can}}$.

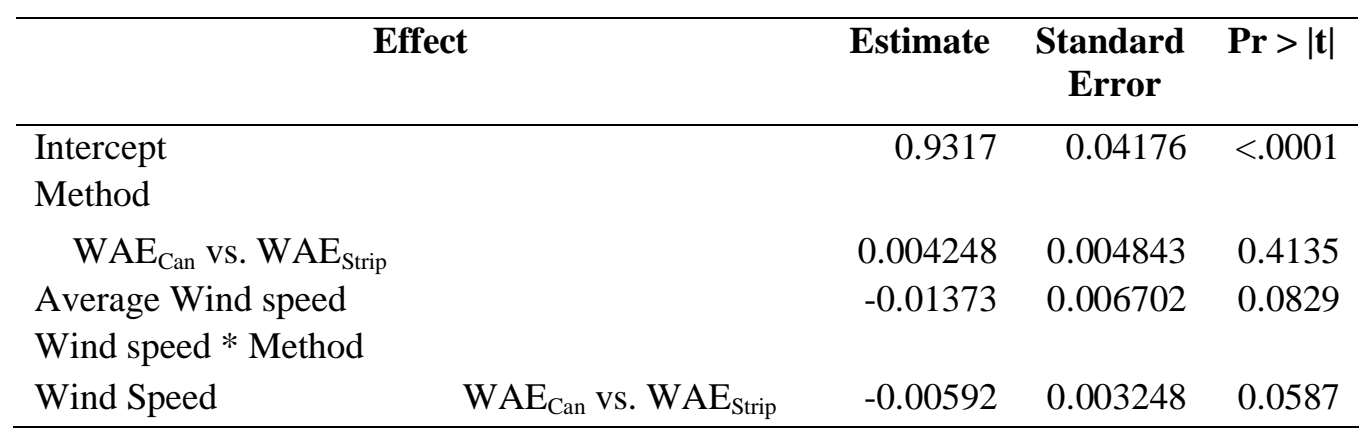


Table 4. Mixed modeling effects for $\mathrm{WAE}_{5 \min }$

\begin{tabular}{cccccc}
\hline Effect & Estimate & $\begin{array}{c}\text { Standard } \\
\text { Error }\end{array}$ & DF & t Value & Pr $>|\mathbf{t}|$ \\
\hline Intercept & 1.0518 & 0.02733 & 9.17 & 38.48 & $<.0001$ \\
Temperature & -0.00462 & 0.00097 & 7.87 & -4.77 & 0.0015 \\
Wind Speed & -0.0264 & 0.00331 & 13.3 & -7.97 & $<.0001$ \\
\hline
\end{tabular}




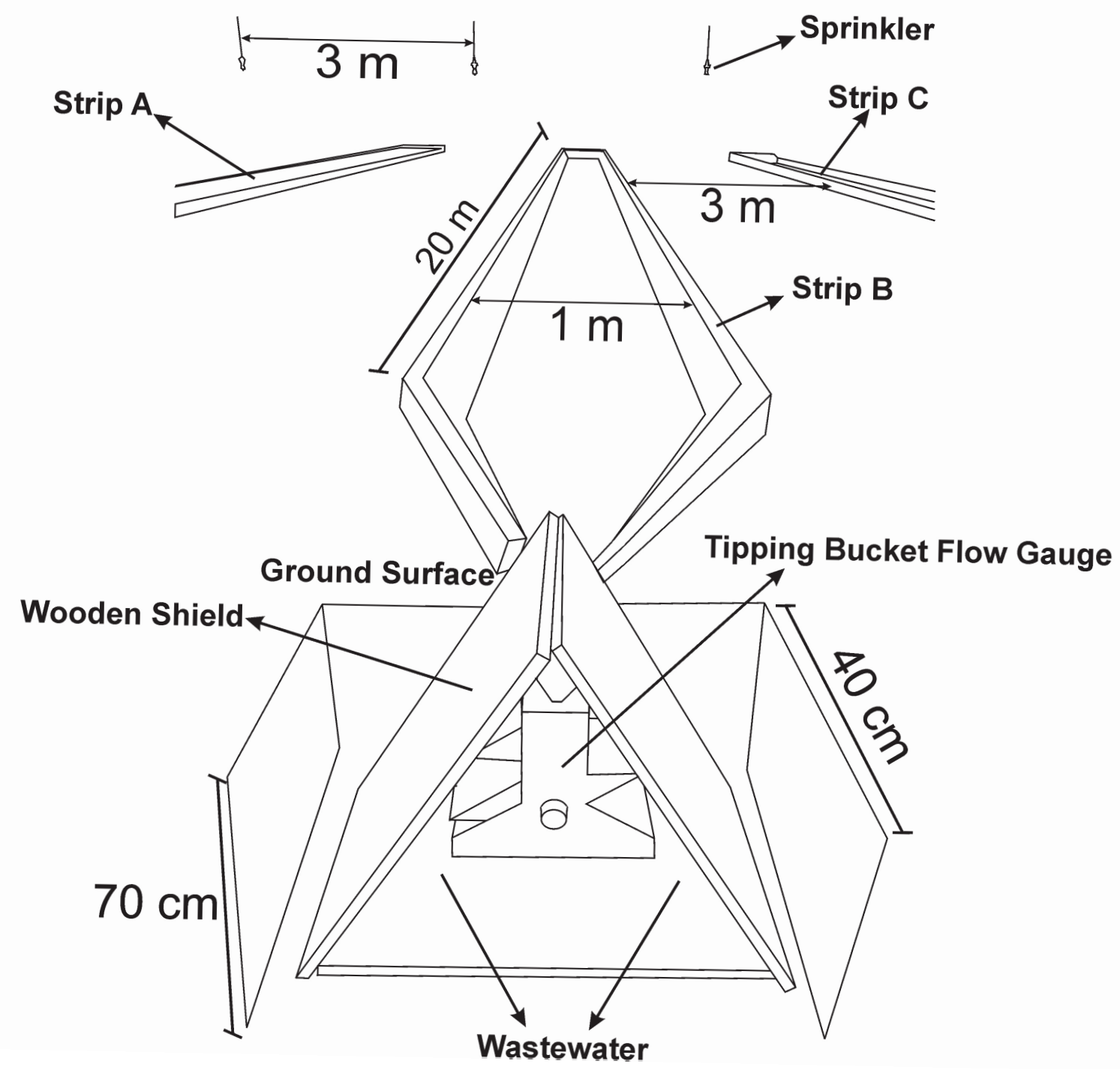




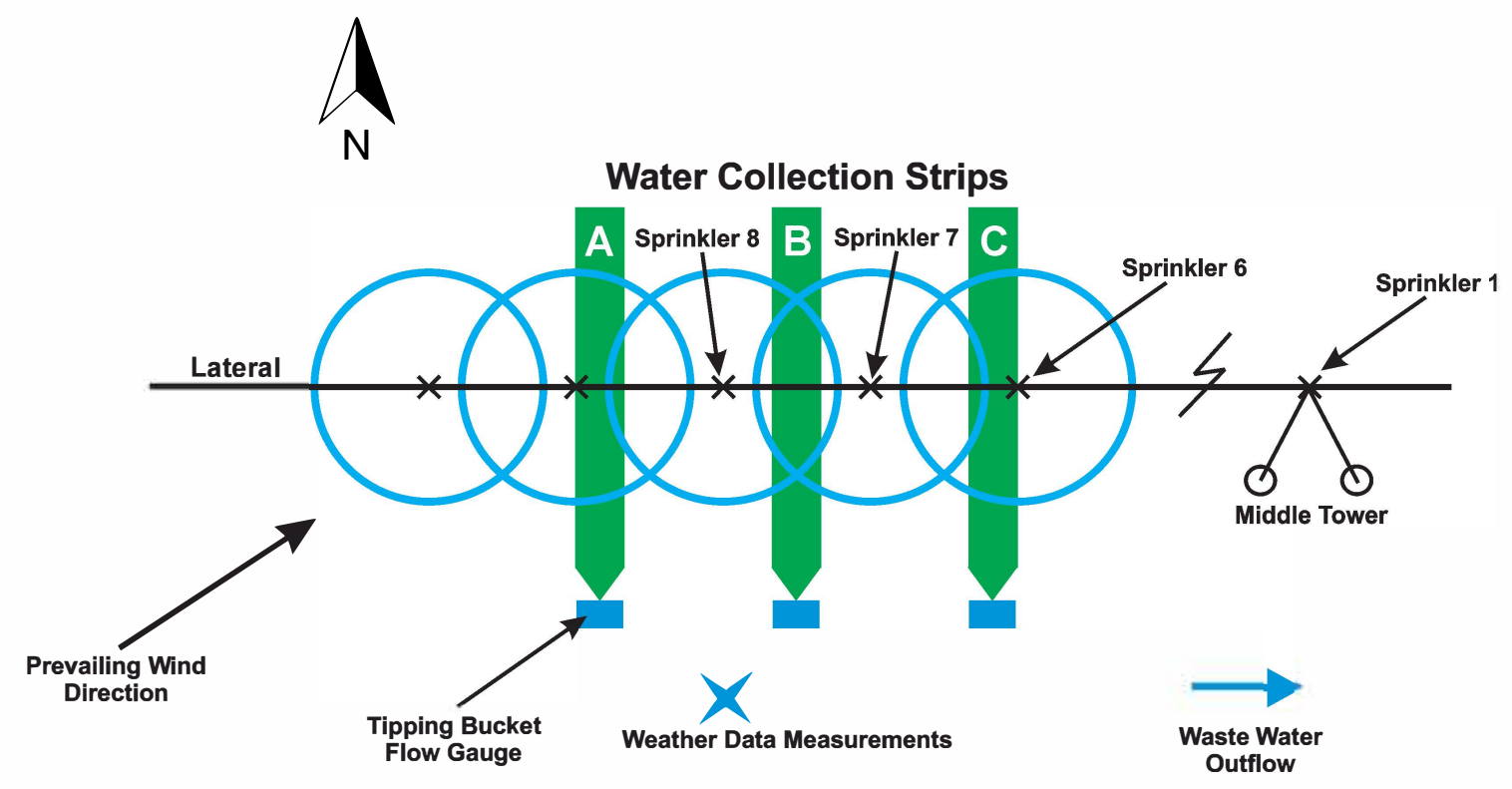




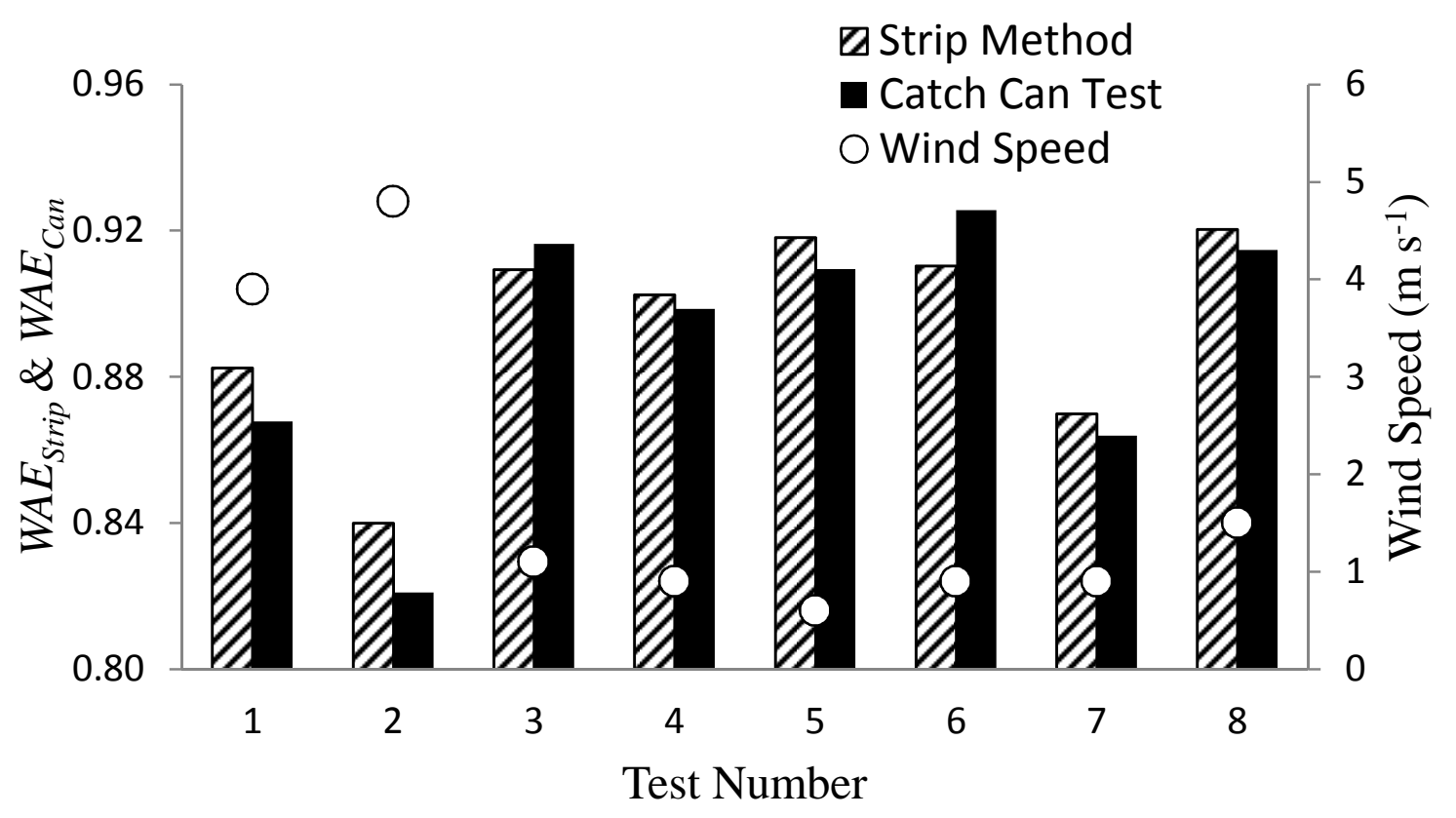

Figure 3. $W A E_{\text {Strip }}, W A E_{c a n}$ and average wind speed. 


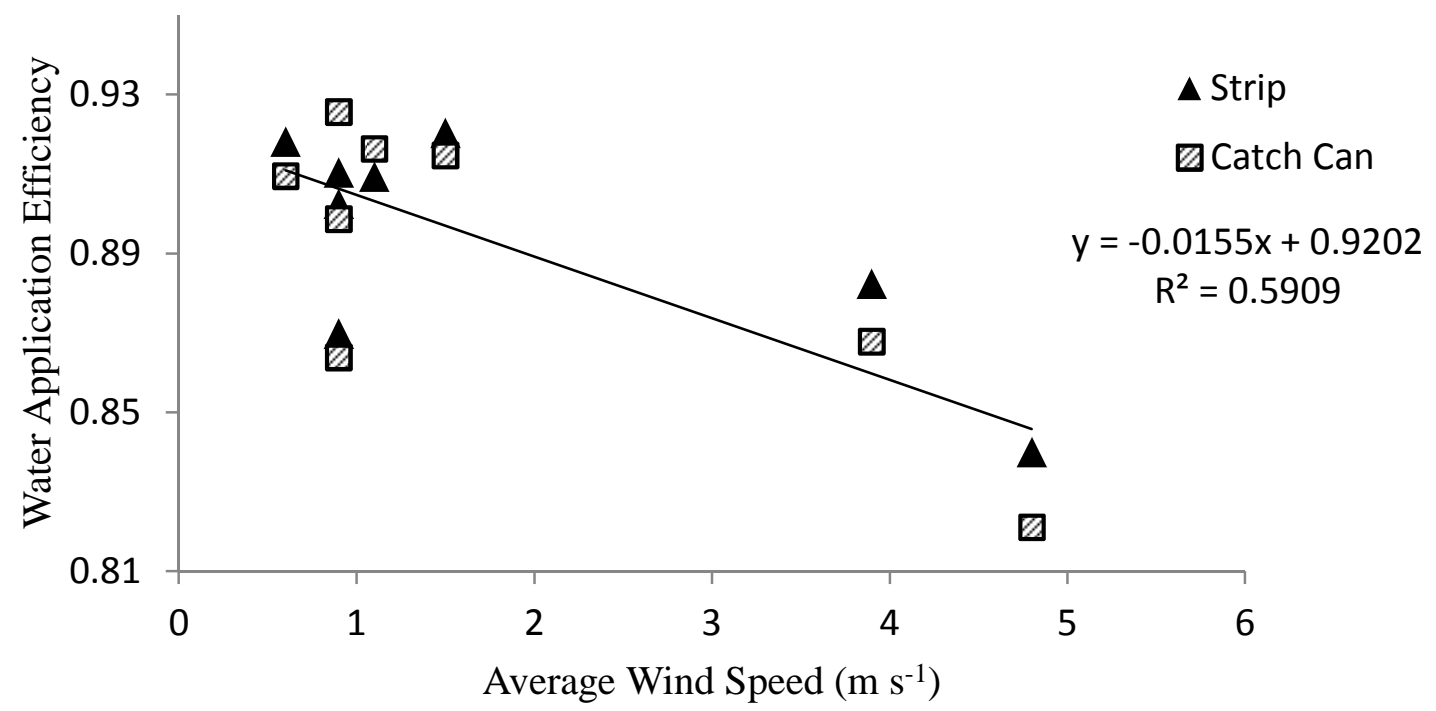

Figure 4. Linear relationships between wind speed $\left(\mathrm{m} \mathrm{s}^{-1}\right)$ and $W A E_{\text {Strip }}$ and $W A E_{C a n}(\mathrm{P}<0.001)$. 


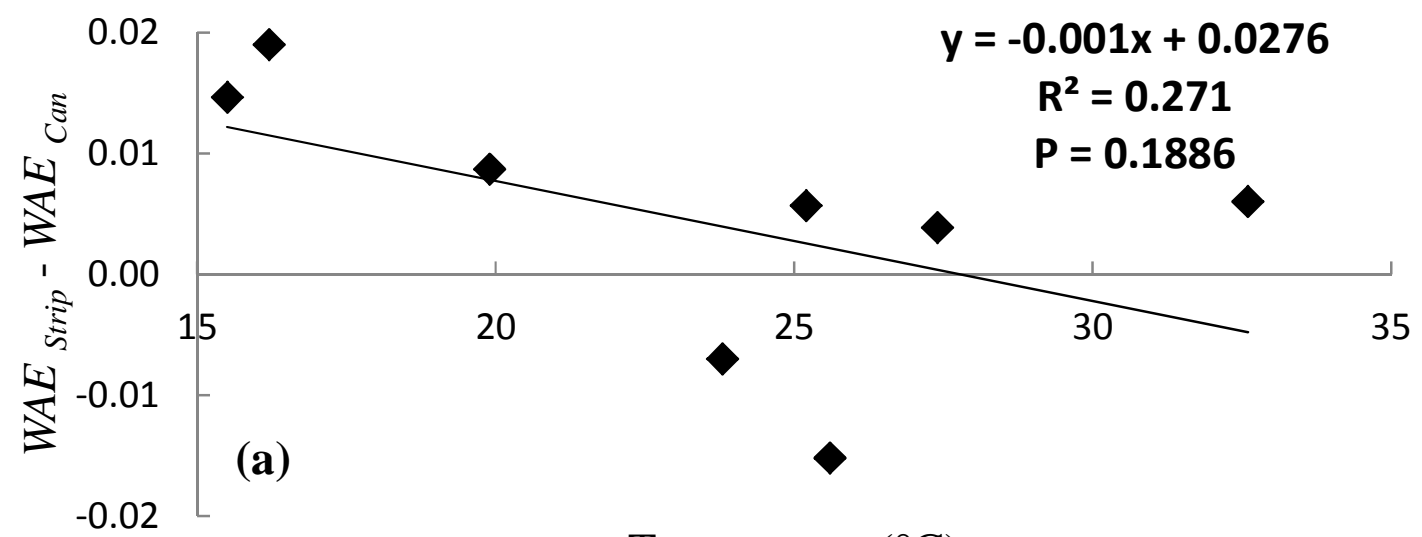

Temperature $\left({ }^{\circ} \mathrm{C}\right)$

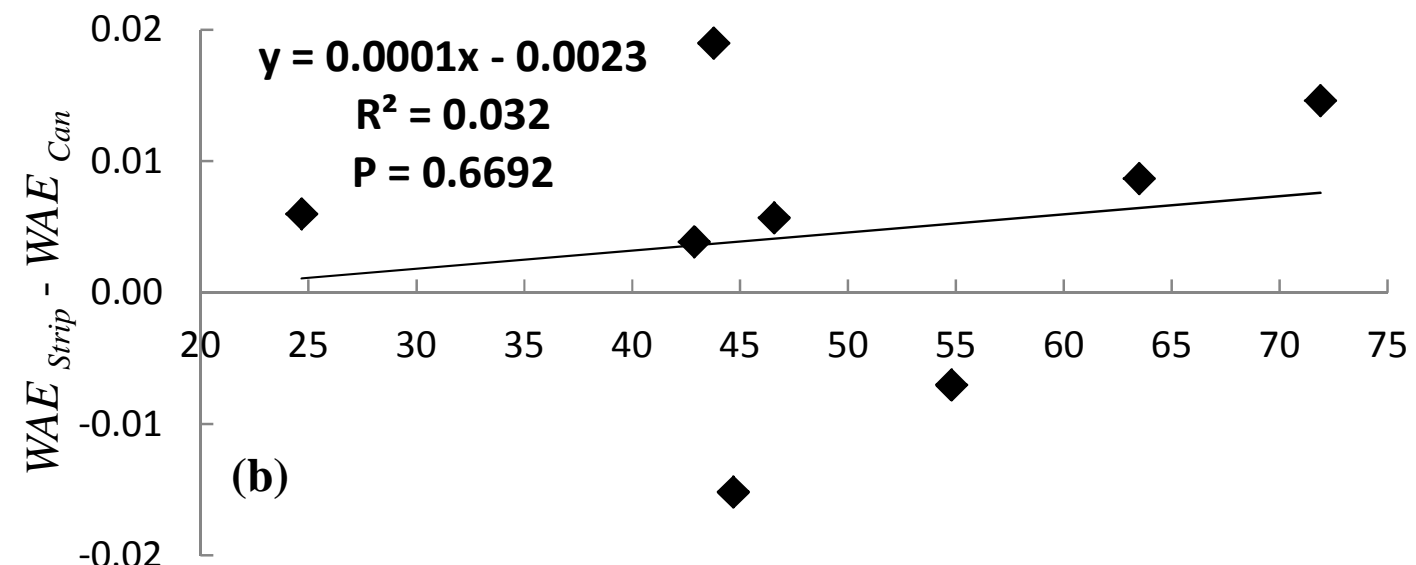

Relative Humidity

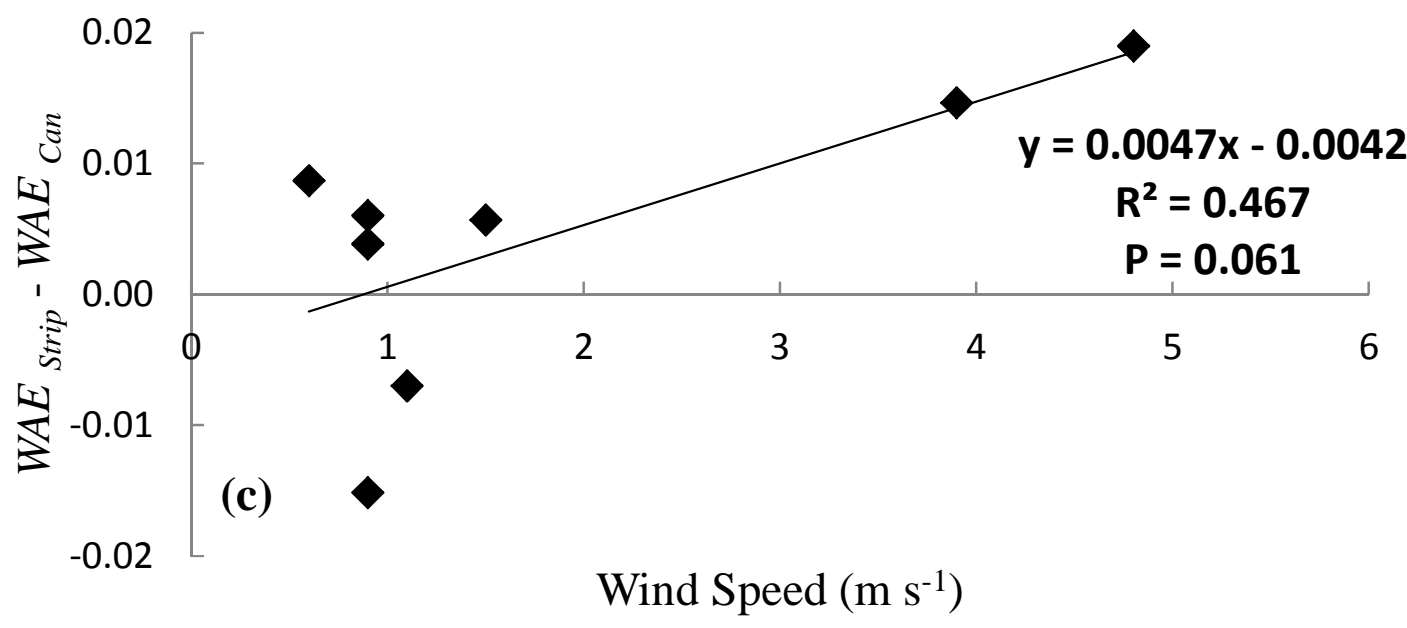

Figure 5. The linear relationship between the residuals from $W A E_{\text {Strip }}-W A E_{c a n}$ and (a) air temperature, (b) relative humidity, and (c) wind speed. 


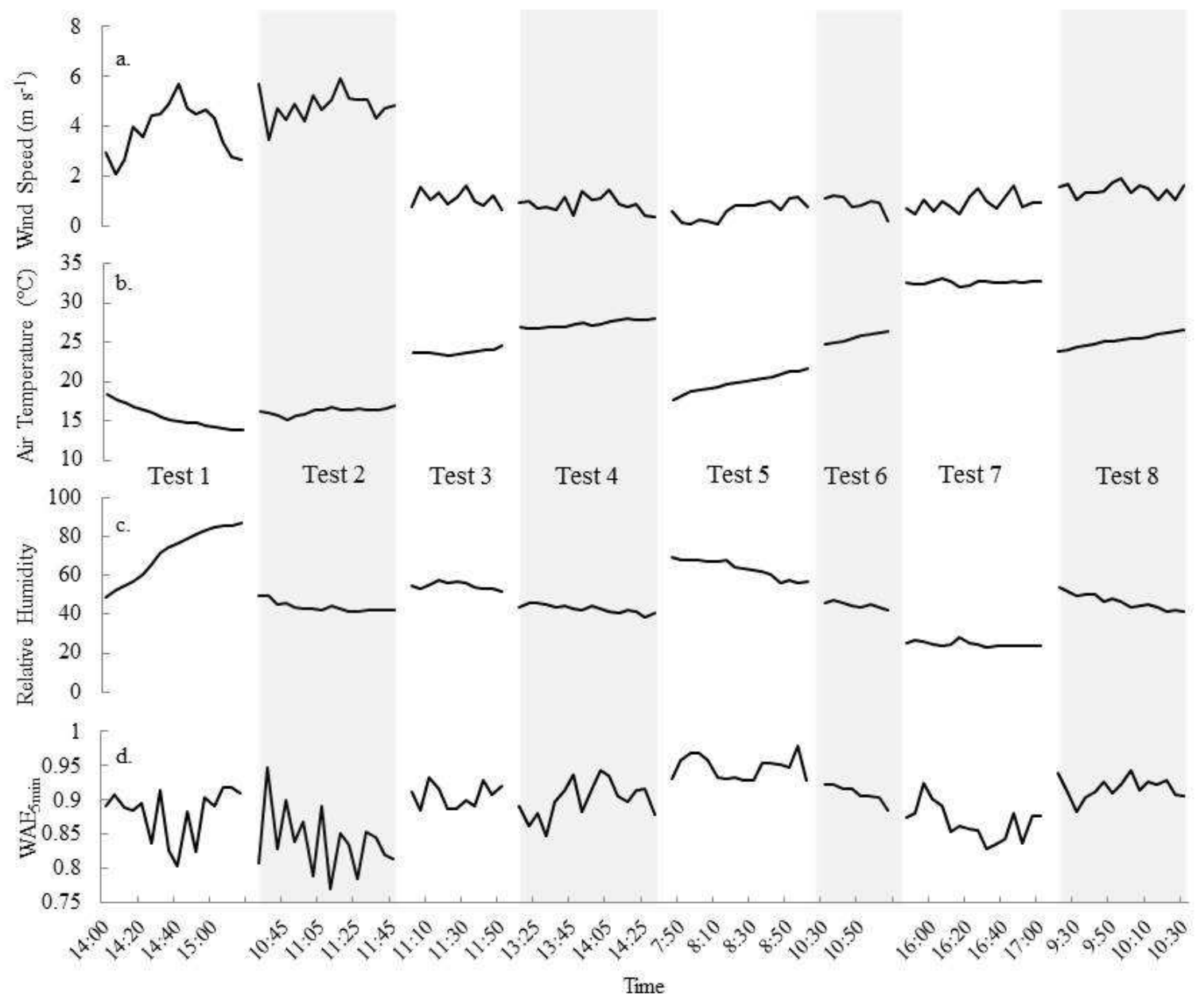

Fig 6. Time series of (a) wind speed, (b) air temperature, (c) relative humidity, and (d) the $\mathrm{WAE}_{5 \min }$ for each test. 